\title{
СИНТЕЗ И ПРОГНОЗ БИОЛОГИЧЕСКОЙ АКТИВНОСТИ 5-АМИНОЗАМЕЩЕННЫХ 3-БРОМ-4-НИТРО-1-(1,1- ДИОКСОТИЕТАНИЛ-3)ПИРАЗОЛОВ
}

\author{
С.О. Шепилова, Е.Э. Клен \\ Кафедра фармацевтической химии, Башкирский государственный медицинский \\ университет, 450008, Россия, Уфа, ул.Ленина, 3.
}

DOI: 10.19163/MedChemRussia2021-2021-484

e-mail: svetikshepilova@mail.ru

Одной из приоритетных задач фармацевтической химии на сегодняшний день остается синтез новых биологически активных веществ. Перспективными являются производные пиразола, которые широко применяются как противовоспалительные (Celecoxib), противоопухолевые (Crizotinib), антикоагулянтные (Apixaban), гипогликемические (Teneligliptin) ианксиолитические (Mepiprazole) средства.

В продолжение исследований по синтезу производных 1-(тиетанил-3)пиразола [1] нами исследованы реакции 3,5-дибром-4-нитро-1-(1,1диоксотиетанил-3)пиразола (2) с аминами. Исходный пиразол 2 полученокислением 3,5-дибром-4-нитро-1-(тиетанил-3)пиразола (1) пероксидом водорода. Установлено, что реакции пиразола 2 с первичными и вторичными аминами гладкопротекают при кипячении в этаноле. 5-Аминозамещенные 3-бром-4-нитро-1-(1,1-диоксотиетанил-3)пиразолы (3-6) образуются с выходом до $80 \%$.

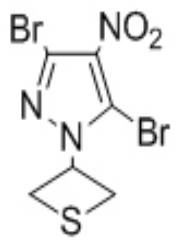

1

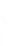

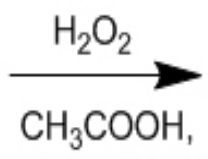

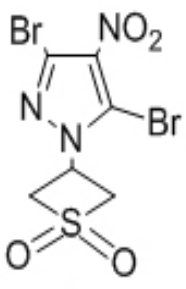

2

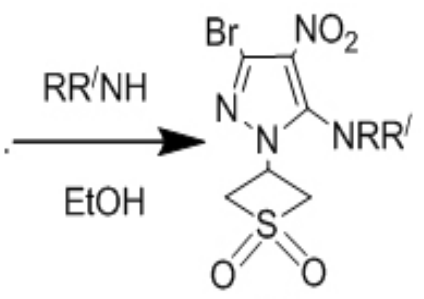

3-6

Структура синтезированных соединений подтверждена данными ИК-, ЯМР ${ }^{1} \mathrm{H}$ и $\mathrm{C}^{13}$ спектров. Результаты прогноза биологической активности в программе PASS online показали, что 5-аминопроизводные 3-6 с вероятностью более 0,7 могут быть использованы для лечения эндометриоза и других гинекологических заболеваний.

\section{Литература}

[1]. F. A. Khaliullin, E. E. Klen, N. N. Makarova [et al.], Chemistry of Heterocyclic Compounds. 2020, 56, 1213-1217. 